University of Rhode Island

DigitalCommons@URI

Open Access Master's Theses

1952

\title{
The Effect of Various Organo-Phosphorous Compounds on the Thermal Degredation of Cellulose
}

\author{
Michael Antoni \\ University of Rhode Island
}

Follow this and additional works at: https://digitalcommons.uri.edu/theses

\section{Recommended Citation}

Antoni, Michael, "The Effect of Various Organo-Phosphorous Compounds on the Thermal Degredation of Cellulose" (1952). Open Access Master's Theses. Paper 1363.

https://digitalcommons.uri.edu/theses/1363

This Thesis is brought to you for free and open access by DigitalCommons@URI. It has been accepted for inclusion in Open Access Master's Theses by an authorized administrator of DigitalCommons@URI. For more information, please contact digitalcommons-group@uri.edu. 
THE EFFECP OF VARIOUS ORGANO-PHOSPHOROUS COMPOUNDS

ON THE THERMAL DEGRADATION OF CELLULOSE

BY

MICHAEL ANTONI

A THESIS SUBMITIED IN PARTIAL FULFILLMENT OF TEE

REQUIREMENS FOR THE DEGREE OF

MASTER OF SCIENCE

IN

CHEMISTRY 
MASTER OF SCIENCE THESIS

OF

MICHAEL ANPONI

Approved:

Major Professor

W.

Y.

Head of Department

w.

Lesen

Dean of the College of Arts and Sclencedardedestrowomm Director of Graduate studies_. Verion \&Cheadle

University of Rhode Irland

1952 


\section{ABSTRACT}

The thermal decomposition products of cellulose treated with various organo-phosphorous compounds were investigated.

The function of a flame-retardant in cellulose is to favor the production of carbon and water rather than flammabie tarry products which are formed in the thermal degradation of untreated cellulose. Furthermore, if the oxidation of the charred residue 18 directed toward the production of carbon monoxide rather than carbon dioxide, it is belleved that the heat produced in this reaction would not be oufflolent to sustain an afterglow when the flame has been removed.

A comparison was made between the amounts of char and tar produced and the efficlency of the retardanta used. A correlation between the carbon monoxide-carbon aloxide ratio and the afterglow exhibited by treated cotton was made.

The regults obtalned support the theory that flameresistant cellulose produce less flammable tars and more carbon monoxide than untrested cellulose. However, no significant afferentiation as to the relative effectiveness of the various compounds investigated was possible.

It is suggested that further studies be completed on the varlous types of compounds exhibiting fire-retardancy to provide a more general theory of fire-resistant celluloge. 


\section{TABLE OF CONTENPS}

PAGE

TABLE OF CONTENTS......................... 1

I. INTRODUCTION............................ 3

II. REVIEW OF LIMERATURE..................... 6-10

III. INVESTIGATION....................... 11-26

A. ОВगЕСТ........................ $11-12$

B. THEORETICAL DISCUSSION.............. 13-16

c. APPaRatus and Matertals.............. 17-21

D. PROCEDURES....................... 22-24

1. Preparation of the Retardant.......... 22

2. Preparation of the Sample........... 22

3. Combustion Method.................. 23

4. Pyrolys16 Method.................... 23

5. Oxidation Method.................... 24

E. RESULTS......................... 25-26

IV. DISCUSSION OF RESULTS AND CONCLUSION.......... 27-29

v. SUMMARY.......................... 30-31

VI. ACKNOWLEDGEMENTS..................... 35

VII. BIBLIOGRAPHY...................... 36-37 TABLES

1. Char-Tar Ratio of Cellulose Treated with Catalytic Amounts of Flame-Retardants........

2. Char-Tar Ratio of Cellulose Preated with 15-25\% Add-on of Flame-Retardants.......... 


\section{TABLE OF CONTENTS (continued)}

PAGE

3. Char-Volatiles and $\mathrm{CO}-\mathrm{CO}_{2}$ Ratio of Cellulose Treated with Catalytic Amounts of Flame-Retardants.

4. Char-Volatiles and $\mathrm{CO}-\mathrm{CO}_{2}$ Ratio of Cellulose Treated w1th 16-20\% Add-on

of Flame-Retardant $6 . . \ldots \ldots \ldots \ldots \ldots \ldots \ldots \ldots$.

FIGURES

1. COMBUSTION APPARATUS

2. PYROLYSIS APPARATUS................. 20

3. OXIDATION APPARATUS................. 21 APPENDIXES..................................... $32-34$ 


\section{INTRODUCTION}

During the past few years considerable progress has been made in the development of methods for reducing the flamability of textile fabrics, particularly cotton 1abrics. The increased interest in this problem was caused by the use of many incendiary type weapons in modern warfare. The need for efflclent methods for producing flame-resistant military fabrics became all too apparent and several military projects were established to invertigate this problem.

The first project was established in the Department of Chemical Engineering at Columbia University in 1942, under the sponsorship of the National Research Counc1l Committee on Quartermaster Problems (1). The objectives of this project were:

(1) Improvement of existing flame-resistant treatments for cotton for temporary use; (2) Investigation of the fundamental principles of flame retardancy, which included the study of the mechenisms by whlch flameretardant chemicals function to decrease the combustibility of textile fabrics; and (3) search for more efficient flame-retardant agents and improved methods to provide a more atiafactory treatment of rabrics for military use.

As was the case with many developments and projects made necessary by war, the problem of producling flaneresiatant fabrics for civilian use was of immediate interest to the consuming public. This is evidenced by 
recent publicity regarding "torch sweaters" and other sportswear of high flammability. Several stateg have already adopted restrictive legislation regarding this hazardous situation, and have imposed rigid regulations on the manufacture and sale of such fabrics.

Many associated problems arise from the application of a flame-retardant to textile fabrics. Requirements other than the flame-retardant properties must be met. The treated fabric must not be injurious to the okin and must retaln the qualities it possessed before treatment. The tensile strength must be maintained and care must be used not to cause stiffening. Many fire-retardants reduce the tear resistance of the fabric and have a detrimental effect on the dye. The clothing fabric must remain comfortable to the wearer, insofar as moisture, heat, and rentilation are concerned.

The injury caused the wearer of clothing whlch becomes ignited results from the thermal transfer of the heat evolved to the body. The heat produced by the thermal degradation of textiles of a cellulosic nature comes from a serieg of complicated reactions and may be summarized as follows (2):

(1) Flaming Source $\longrightarrow \Delta \mathrm{H}_{1}$

(2) Cellulose $\longrightarrow$ Decomposition Products $+\Delta \mathrm{H}_{2}$

(3) Volatile Decomposition Products $+\mathrm{O}_{2} \rightarrow \mathrm{CO}_{2}+\mathrm{H}_{2} \mathrm{O}+\Delta \mathrm{H}_{3}$

(4) Solid Decomposition Products $+\mathrm{O}_{2} \longrightarrow \mathrm{CO}+\mathrm{CO}_{2}+\Delta \mathrm{H}_{4}$ 
The oxidation of the solid decomposition products is the process which is belleved to propagate an afterglow when the flame has been removed. In this investigation the rlame-resistance and effect on the afterglow of various organo-phosphorous compounds on cellulose was studied. 


\section{REVIEW OF LITERATURE}

The exact mechanisms of the reactions involved in the degradation of cellulose are not yet fully understood because of their complex nature. It has been substantiated, however, that the thermal degradation of cellulose occurs in three steps (3). The primary reaction involves the initial decomposition at flame temperatures resulting in the formation of a charred residue composed mainly of carbon, a highly flammable tarry diatillate, and a volatile fraction composed of water and gases. The second step is a rapld reaction which involves the cracking and flaming of the tarry distillate. A phenomenon known as afterglow is the final reaction. Thts reaction is a much slower decomposition which causes the oxidation of the charred residue resulting in an exothermic reaction which propagates a glow after the flame has been removed.

The charred realdue is composed of carbonaceous material having much the same structure as the original cellulose and the decomposition products of the added flame retardent. The tarry constituents contain hydroxyl, methylene, methyl, carbonyl, ethylene and ester groupings as determined by their infrared absorption spectra. These products are in agreement with the theoretical considerations regarding the probable course of the disintegration of the cellulose molecule (4a). Little (5) found that the tars were practically insoluble in water, slightly soluble in 18opropanol, and very soluble in acetone. The carbon and 
hydrogen content appears to vary slightly depending on the chemical retardant added before combustion. The aldehyde content is affected in the same manner. Tars from cellulose treated with different retardants showed no appreciable differences in the rate of flaming. The function of an effective retardant would therefore not produce a pronounced change in the composition of the tar but rather reduce the amount of tar produced.

The volatile fraction consists of gases including carbon dioxide, carbon monoxide and some methane, and an aqueous distilate. The aqueous liquor contalns aldehydes, ketones, furfural and pyroligeneous substances (6).

Heuser (7) reported that Ramsay and Chorley found the rarious phase in the thermal decomposition of cellulose take place in distinct steps. Water is produced at $200^{\circ} \mathrm{C}$, depending on the rate the temperature is increased. Above $200^{\circ} \mathrm{C}$, the tars begin to appear and the evolution of gases is initiated. At about $270^{\circ} \mathrm{C}$. , the reaction becomes violent and no more decomposition products are formed. At this temperature the reaction becomes exothermal and it $1 \mathrm{~s}$ believed that this 1s where the secondary and tertiary reactions take place. Further increase in the temperature causes a distillation of some of the products already formed and at $470^{\circ} \mathrm{C}$. the reaction ceases. Copplck (4b) found that the exothermic reaction accompany ing the rapid formation of decomposition products does not occur in the absence of air. During pyrolysis, this reaction takes place 1sothermally. This 
would indicate that at least part of the decomposition is caused by oxidative degradation.

Coppick (8) stated that the mechanism whereby a

flame retardant becomes effective must be classified in one of three possibilities. The first is the retardation of the thermal decomposition of the cellulose, because without decomposition no flammable vapors can be produced. This retardation may be brought about by inhibition of the decomposition reaction by the addition of a negative catalyst or by the removal of an already present positive catalygt. The changes in the thermal conductivity properties of cellulose should also merit consideration as well as physical insulation of the flber by a protective coating of the retardant.

The second possibility is the direction of the carbonaceous decomposition reaction products toward nonvolative products. This reaction would mean that all of the carbon would be directed toward the elemental state without passing through any intermediate flammable stages.

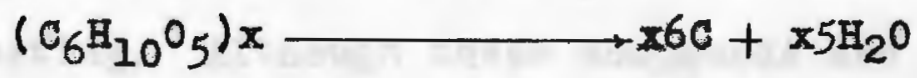

The final possibility is that if volatile carbonaceous products must be produced, direction toward a highly oxldized, non-flammable type would be preferred. This reaction would require the addition of an oxidizing agent to take the place of the oxygen normally supplied by the air.

$$
\left(\mathrm{C}_{6} \mathrm{H}_{10} \mathrm{O}\right) \mathrm{x}+\mathrm{x} 6 \mathrm{O}_{2} \longrightarrow x 6 \mathrm{CO}_{2}+\mathrm{x} 5 \mathrm{H}_{2} \mathrm{O}
$$


The many llame-resistant compounds and treatments avallable for textile fabrics may be clasified on the basis of the chemical nature of the active ingredients, the mechanism by which they are believed to function, the permanence of the flame-resistant characteristics in terms of resistance to wet- and dry-cleaning operations, or the mathod of attachment to the fiber (9). Most of the retardants employed have been grouped according to these otandards.

The compounds most generally regarded as flame retardants are inorganic salts which appear to function by the formation of a foam which serveg as a blanket between the fabric and the Ilame. This group 18 composed of low-melting salta which form a foam with the decomposition products. Examples of thls group are borax, aluminum sulfate, mixtures of borax and boric acid with and without added ammonium phosphates, borax and diammonium phosphate, and sodium phosphate-boric acid mixtures (9).

A less effective group of flame-retardants are water soluble inorganic acids and salts capable of liberating aclas upon heating. Although these compounds are not as efficient as the previous group in preventing afterfleming, they are nevertheless more effective in preventing afterglow. Representatives of this group are sulfuric, sulfamic, boric, phosphoric, hydrochloric, hydrobromic, molybdic, and tungatic ac1ds, their ammonium salts, and salts of organle bases such as urea, ethylenediamine, and the alkyl and alkylol amines (9). 
The efficiency of these compounds results from their ability to furnish an acid or acid anhydride at the time of incipient flaming.

The organo-phosphorous compounds used in this investigation are believed to release phosphoric acid at flaming temperatures, and also catalyze the degradation of - 1 lulose toward less flammable products. It has been shown that with the flame-resistant and glow-resistant fabrics of the phosphated type, the rate and temperature increase and the maximum temperature attained under the fabric compares farorably with almilar data for asbestos paper or glass-asbestos fabric of similar thickness (3b). This thermal protection is directly attributed to the insulation provided by combustion-resistant carbonaceous layer. 


\section{THE INVESTIGATION}

A. OBJECT

The object of this investigation was to study the effects of varlous organo-phosphorous compounds on the thermal degradation of cellulose. The apparatus and experiments were designed to provide the following information:

1. The amount of charred residue and flammable tars produced from the combustion and pyrolysis of cellulose treated with various organo-phosphoroug compounds.

2. A correlation between the producte of the thermal degradation of cellulose and the effect on fireretardancy of the added organo-phosphorous compounds.

3. The rat10 of carbon monoxide to carbon dioxide produced in the oxidation of the charred residue from the pyrolysis of treated cellulose.

4. A correlation between the carbon monoxide-carbon dioxide ratio and the effect that the organophosphorous compounds have on the glow-resistance of cellulose.

5. Investigation of the possibility of one or more of these compounds directing the decomposition of cellulose toward the production of less flamable tars and greater ratio of carbon monoxide to carbon dioxide. 
6. Investigation of what effect catalytic amounts of these retardants have on the fire-retardancy of cellulose and comparison of this effect with a larger add-on. 


\section{B. THEORETICAL DISCUSSION}

A satisfactory mechanism for the thermal degradation of cellulose has not been substantiated, but it 18 known that the function of the flame-retardant is to favor the production of carbon and water rather than the decomposition to flammable tarry products which are favored in the degradation of untreated cellulose.

The targ produced from treated cellulose vary only slightly in composition with the tars from untreated cellulose. They appear to be of the same composition and are fairly similar in flamability. Therefore, the main effect of a retardant is not to alter the composition or the flammability of the tar, but to reduce the yleld.

Gases from treated and untreated cellulose show no appreciable change in composition and the production of earbon dioxide does not vary. These results indicate that gases have no relation to the flammability of cellulose. This conclusion must not be confused with the relation of gases to afterglow.

An analysis of the resultant char showed that it is composed of 85 to 90 per cent carbon, small amounts of oxygen, hydrogen and ash constituted the remainder. The relative efficiencies of the various flame-retarding compounds are fairly closely related to their ability to convert the cellulose at flame temperatures to large ylelda of this non-volatile carbonaceous material. When 10 to 15 per cent of the effective retardants are added to 
cotton, the carbon residue is increased from 10 to 40 per cent of the original cellulose. Further addition of the retardant has littie if any effect on the amount of the char produced $(3 c)$.

cellulosic materials have a tendency to exhibit a glow type of combustion after the flame has been atinguished. This afterglow is an exothermic reaction and is often more injurious than flaming itgelf. It is an 1mportant phase in the study of the thermal degradation of cellulose. The afterglow is caused by the oxidation of the resultant carbonaceous char. The propagation of the glow is belleved to be caused by the high exothermicity of the reaction. The direction of this oxidation toward a less exothermic reaction would result in a decrease in afterglow.

The principal gases produced in the oxtdation of carbon are carbon dioxide and carbon monoxide. The production of the former is a much more exothermic reaction. If the oxidation 18 promoted in the direction of carbon monoxide formation rather than of carbon dioxide, the heat of the reaction is reduced from 94.4 to 26.4 rilocalories per mole (40):

$$
\begin{aligned}
& \mathrm{C}+\mathrm{O}_{2} \longrightarrow \mathrm{CO}_{2} \Delta \mathrm{H}=94.4 \mathrm{kc.} \\
& \mathrm{C}+\frac{\mathrm{t}}{\mathrm{a}} \mathrm{O}_{2} \longrightarrow \mathrm{co} \Delta \mathrm{H}=26.4 \mathrm{kc.}
\end{aligned}
$$

These data indicate that the f1rst reaction 18 the one that sustains the glow and the second is of insuffiolent 
exothermicity to propagate afterglow after the flame has been removed.

The phosphoric acid released from the organo-phosphorous oompounds at flaming temperatures is believea responsible for the decreased exothermic production of carbon monoxide. The mechanism favoring this reaction may involve changes in energy barriers (heats of activation) for the two reactions or it may proceed by the following reactions (4c):

$$
\begin{aligned}
2 \mathrm{H}_{3} \mathrm{PO}_{4}+5 \mathrm{C} & \longrightarrow 2 \mathrm{P}+5 \mathrm{CO}+3 \mathrm{H}_{2} \mathrm{O} \\
4 \mathrm{P}+5 \mathrm{O}_{2} & \longrightarrow 2 \mathrm{P}_{2} \mathrm{O}_{5} \\
\mathrm{P}_{2} \mathrm{O}_{5}+5 \mathrm{C} & \longrightarrow 2 \mathrm{P}+5 \mathrm{CO}
\end{aligned}
$$

It is also possible that the phosphate may be absorbed on the active centers of the carbon resulting in a decrease In aotivity. The surface sorption may be similar chemically to the graphitic acid type, such as graphitic bisulfate or fluoride. The following diagrams illugtrate such a reaction (4d):

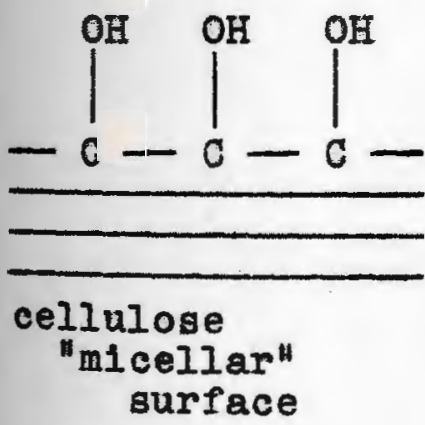

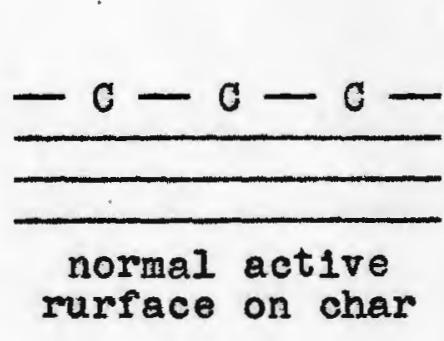

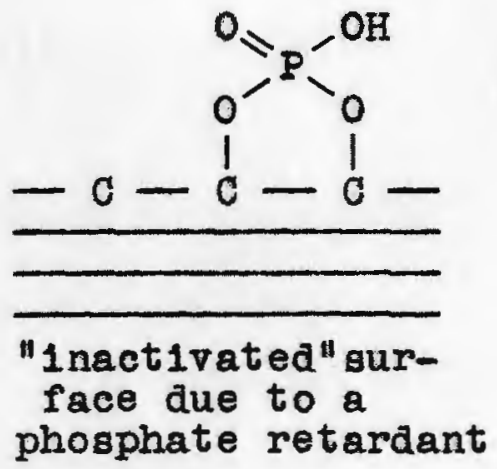

phosphate retardant

The method used for studying the products of the combustion of cellulose is similar to the procedure used by Copplok (4e). 
It was found that the temperature attained by burning a Labric is approximately $500^{\circ} \mathrm{C}$. and complete combustion of a cample required less than 15 minutes. A rate of $100 \mathrm{cc}$. of air per minute was sufficient for complete oxidation. The combustion reactions in this investigation were performed at a temperature of $500^{\circ} \mathrm{C}$. Each sample was allowed to burn 15 minutes. In order to insure complete combustion, an air flow of $180 \mathrm{cc}$. per minute was maintained.

The pyrolysis procedure used was similar to that described by Copplak ( $4 f$ ) with a modfled pyrolysis tube. The experimental conditions were $500^{\circ} \mathrm{C}, 20 \mathrm{~mm}$. of mercury and 15 minutes pyrolysis time. 


\section{APPARATUS AND MATERIALS}

1. Absorbent cotton, U.S.P. sterile, was used in all experiments. Cotton is approximately 91 per cent cellulose.

2. The following retardants were investigated: Modifled Triallyl Phosphate Brominated Triallyl Phosphite Brominated Modifled Triallyl Phosphate Brominated b18-Allyl, n-Butyl Phosphate Brominated Anlline Triallyl Phosphite

3. The combustion apparatus as shown in Figure 1. consisted of pyrex glass tubing, seven-eights by eight inches, constricted to approximately three-elghts of an inch one third of the distance from the end to hold the cotton sample. This combustion tube was connected to a trap which was immereed in a salt-ice bath. Air was drawn through the system by a water aspirator. The rate of flow was measured with a dibutyl phthalate flow meter.

4. The pyrolysis apparatus as shown in Figure 2. consisted of a pyrex glass tube, three-fourths by six inches, which was connected to a trap immersed in a salt-ice bath. The system was evacuated by a water aspirator. The pressure was regulated and measured with a standard mercury closed manometer.

5. The oxidation apparatus as shown in Figure 3. consisted of a three inch quartz boat enclosed in a seven-elghts 
by fourteen thch length of pyrex glase tubing. Dry, $\mathrm{CO}$ - and $\mathrm{CO}_{2}$ - free air was passed through the oxidation chamber. The rate of flow was regulated by a dibutyl phthalate flow meter.

6. The electric furnace used in all experiments was composed of a one by eight inch length of quartz tubing around which was wound No. 18 Chromel-A resistance wire. This heater was covered with approximately one inch of asbestos.

7. An Electric Pyrometer was used to regulate the temperature.

8. A Standard Orsat Gas Analygko apparatus was used for the analyais of the gases in the oxidation procedure. 


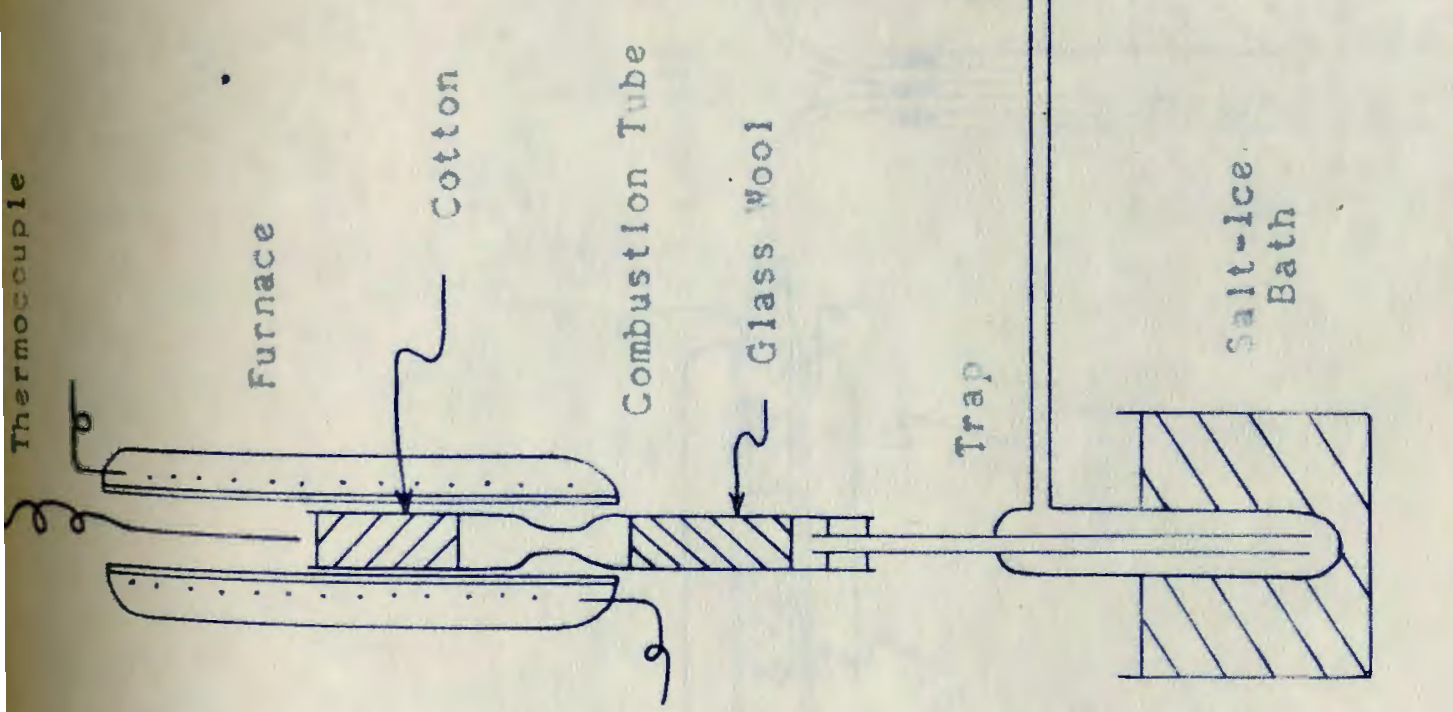




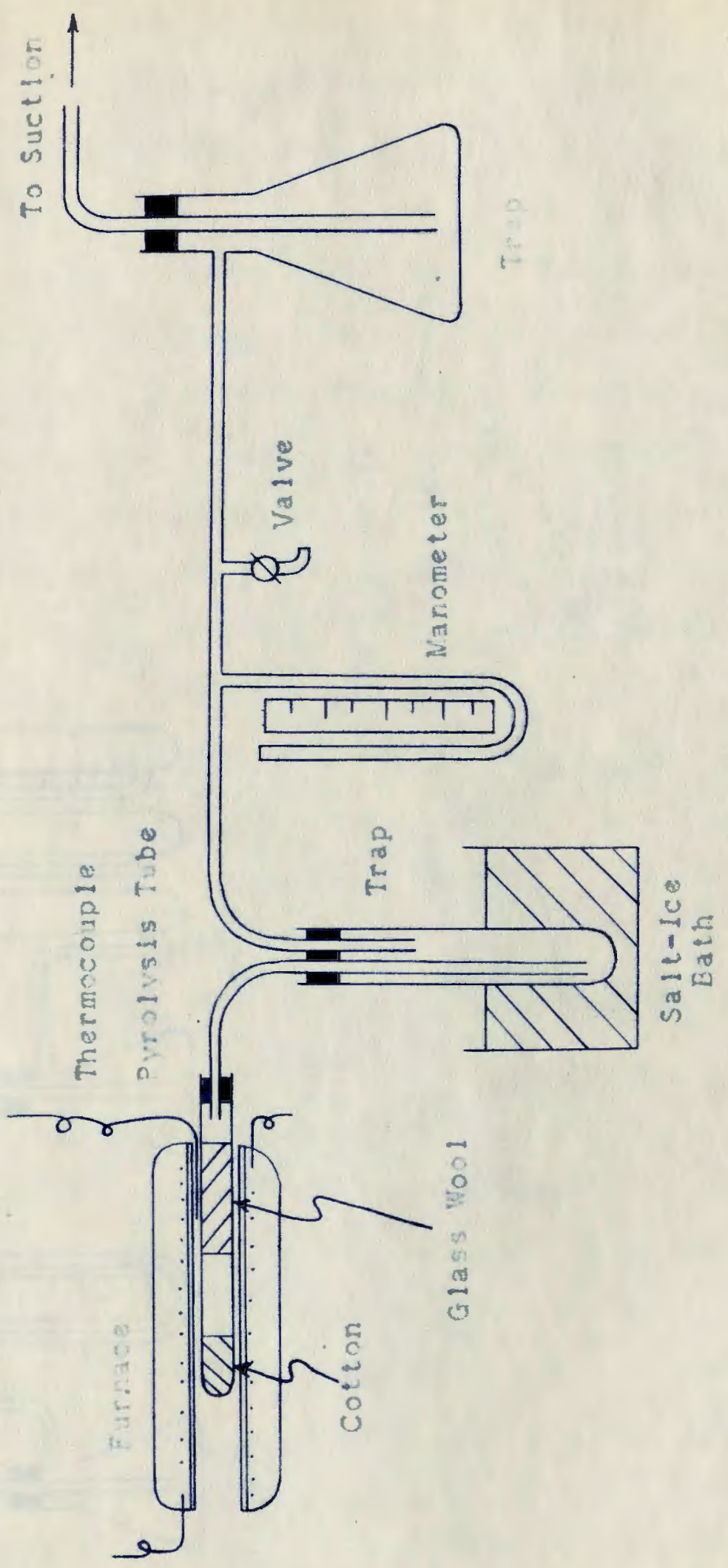

$n$
5
5
5
0
5
5
5
5
5

ru 


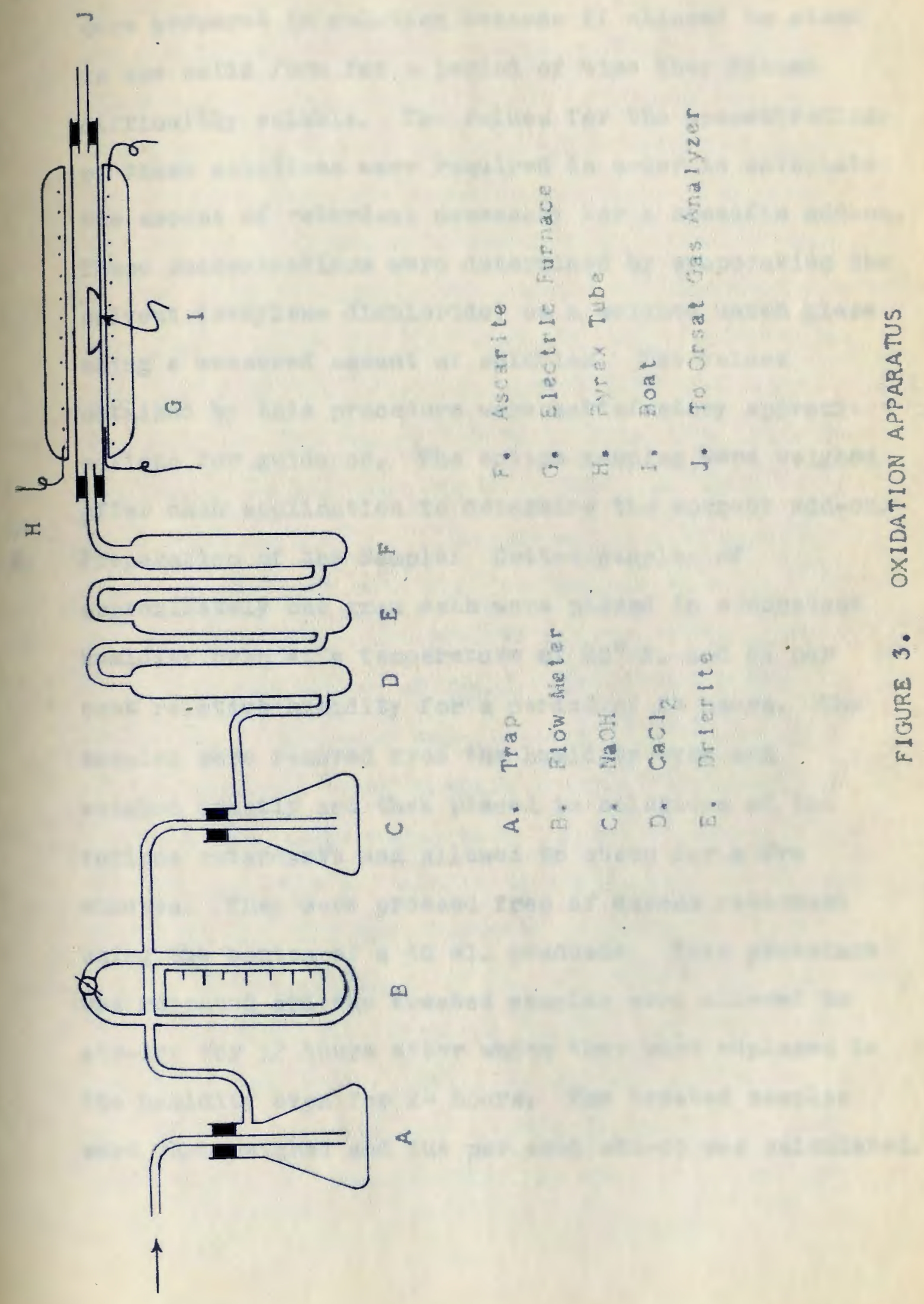




\section{PROCEDURES}

1.

Preparation of the flame-retardant: The retardant were prepared in solution because if allowed to stand in the solid form for a period of time they become diffioulty soluble. The values for the concentrations of these solutions were required in order to caloulate the amount of retardant necessary for a specific add-on. These concentrations were determined by evaporating the solvent (ethylene dichloride) on a weighed watch glass using a measured amount of solution. The values obtalned by th1s procedure were satisfactory approximations for guidance. The cotton samples were weighed after each application to determine the correct add-on.

2. Preparation of the Sample: Cotton samples of approximately one gram each were placed in a constant humldity oven at a temperature of $80^{\circ}$ F. and 65 per cent relative humidity for a period of 24 hours. The samples were removed from the humidity oven and weighed exactly and then placed in solutions of the various retardants and allowed to eteep for a few minutes. They were pressed free of excess retardant using the botton of a $50 \mathrm{ml}$. graduate. This procedure was repeated and the treated samples were allowed to alr-dry for 12 hours after which they were replaced in the humidity oven for 24 hours. The treated samples were then welghed and the per cent add-on was calculated. 
Combustion Method: Approximately one gram of pyrex glass wool was inserted in the longer end of the combustion tube and aried at $120^{\circ} \mathrm{C}$. for 12 hours. After weighing the tube containing the glass wool, the treated cotton was placed in the upper end of the tube. The end of the tube containing the sample was inserted into the eleotric furnace and allowed to burn for 15 minutes at $500^{\circ} \mathrm{C}$. with a flow of air at 180 cc. per minute. The combustion tube was removed and allowed to cool. The char was easily removed to a weighing bottle. The weighing bottle containing the char and the combustion tube, which now contained the flanmable tars entrapped in the glass wool, were both dried at $120^{\circ} \mathrm{C}$. for 12 hours. The weights of the char and the tare were then determined by weighing.

4. Pyrolysis Method: The treated cotton sample was placed in the bottom of the pyrolysis tube and the remainder of the tube was filled with glass wool, with a epace of approximately one-half inch between the sample and the glass wool. This procedure was followed to hold the sample in place when the vacuum was applied. The tube was then connected to the system and evacuated to $20 \mathrm{~mm}$. of mercury and 1nserted Into the horizontal electric furnace, which was controlled at $500^{\circ} \mathrm{C}$. After 15 minutes pyrolygis time, the tube was removed and allowed to cool. The char was removed by breaking the tube and was placed in a 
welghing bottle and aried at $120^{\circ} \mathrm{C}$. for 12 hours. The weight of the char was then determined. 5. Oxidation Method: The residual char from the pyrolysis of the cotton oample was placed in a quart $z$ combustion boat in the oxidation chamber. The chamber was heated to $500^{\circ} \mathrm{C}$. with a continuous flow of dry, $\mathrm{CO}-$ and $\mathrm{CO}_{2}-$ free air $(180 \mathrm{cc}$. per minute). After five minutes oxidation, $100 \mathrm{ml}$. of resulting gas wae collected directly in the orsat Gas Analysis apparatus. The gas sample was analyzed for carbon-dioxide, oxygen and carbon monoxide using potassium hydroxide, Oxsorbent, and ammoniacal cuprous chloride respeotively as absorbents. The $\mathrm{CO} / \mathrm{CO}_{2}$ ratio was calculated. 


\section{E. RESULTS}

Table 1. Char-Tar Rat1o of Cellulose Treated with Catalytic Amounts of Flame-Retardants

Gompound

Blank

Hodifled Triallyl

Phosphate

Brominated Triallyl

Phosphite

Brom. Modified Triallyl

Phosphate

Brom. b1s-Allyl, n-Butyl

Phosphate

Brominated Anlline

Triallyl Phosphite
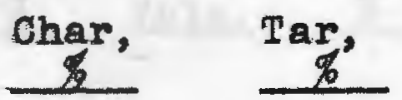

43.36

3.58

18.69

1.49

25.04

1.49

24.33

1.67

20.78

1.35

24.67
Ohar/Tar

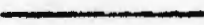

0.1904

.0595

.0612

.0803

.0548

Table 2. Char-Tar Ratio of Cellulose Treated with 15-25\% Add-on of Flame-Retardant

Compound

\section{Blank}

Modifled Triallyl

Phosphate

Bromlnated Trially 1

Phosphite

Brom. Modified Trially

Phosphate

Brom. b18-Allyl, n-Butyl

Phosphate

Brominated Aniline

Priallyl Phosphite

\begin{tabular}{|c|c|c|}
\hline $\begin{array}{c}\text { Char, } \\
\frac{1}{8}\end{array}$ & $\begin{array}{c}\text { Tar, } \\
\text { 息 }\end{array}$ & Char/Tar \\
\hline * & 43.36 & $\ldots$ \\
\hline 15.93 & 19.51 & 0.8165 \\
\hline 11.52 & 18.41 & .6257 \\
\hline 9.55 & 16.16 & .5909 \\
\hline 11.91 & 16.32 & .7297 \\
\hline 15.54 & $17 \cdot 34$ & .8967 \\
\hline
\end{tabular}

(*) Impossible to recover char. 
Table 3. Char-Volatiles and $\mathrm{CO}-\mathrm{CO}_{2}$ Ratio of Cellulose Treated with Catalytic Amounts

of Flame-Retardants

Compound

Blank

Modifled Triallyl

Phosphate

Brominated Triallyl

Phosphite

Brom. Modified Triallyl

Phosphate

Brom. bie-Allyl, n-Butyl

Phosphate

Brominated Aniline

Triallyl Phosphite $\underset{\%}{\text { Char, Char/ } \mathrm{CO}, \mathrm{CO}_{2}, \mathrm{CO} / \mathrm{CO}_{2}}$

$\begin{array}{lllll}7.80 & 0.0850 & 7.8 & 8.2 & 0.947\end{array}$

$\begin{array}{lllll}16.62 & .1993 & 15.4 & 4.6 & 3.348\end{array}$

$\begin{array}{lllll}18.23 & .2229 & 8.8 & 5.0 & 1.760\end{array}$

$\begin{array}{lllll}19.58 & .2434 & 12.5 & 5.4 & 2.314\end{array}$

$\begin{array}{lllll}16.93 & .2038 & 15.8 & 5.3 & 2.981\end{array}$

$\begin{array}{lllll}16.62 & .1993 & 15.8 & 5.4 & 2.926\end{array}$

Table 4. Char-Volatiles and $\mathrm{CO}-\mathrm{CO}_{2}$ Ratio of Cellulose Treated with 10-20\% Add-on of Flame-Retardants

Compound

Blank

Modifled Trially

Phosphate

Brominated Triallyl

Phosphite

Brom. Modifled Triallyl

Phosphate

Brom. bis-Allyl, n-Butyl

Phosphate

Brominated Aniline

Triallyl Phosphite \begin{tabular}{l} 
Char, Char/ $\mathrm{CO}, \mathrm{CO}_{2}, \mathrm{CO} / \mathrm{CO}_{2}$ \\
\hline
\end{tabular}

$\begin{array}{lllll}7.80 & 0.0850 & 7.8 & 8.2 & 0.947\end{array}$

$\begin{array}{lllll}33.45 & .5026 & 7.9 & 6.0 & 1.316\end{array}$

$\begin{array}{lllll}36.22 & .5679 & 9.0 & 6.8 & 1.550\end{array}$

$\begin{array}{lllll}32.09 & .4726 & 9.3 & 6.0 & 1.729\end{array}$

$\begin{array}{lllll}32.68 & .4854 & 12.8 & 7.4 & 1.729\end{array}$

$\begin{array}{lllll}36.11 & .5636 & 12.4 & 7.4 & 1.610\end{array}$ 


\section{DISCUSSION OF RESULTS AND CONCLUSION}

The combustion of cellulose treated with catalytic amounts (approximately one per cent) of the retardants used in this investigation gave no indication as to the relative effectiveness of the compounds. It was cemonstrated that as a group these organo-phosphorous compounds exhibited promise as flame-retardants. The flammable tars produced by the treated amples were reduced by approximately one-half as compared to the untreated sample (Table 1 ).

The cotton samples treated with an increased add-on ranging from 10 to 20 per cent decreased the production of flammable tars by approximately 60 per cent (Table 2). The charred resldues showed a marked increase in weight as compared to the chars from samples which were treated with catalytic amounts of retardant. This increase in weight is probably caused by the decomposition products of the added retardant and would not serve as a correct indication of the efficiency of the retardant. The relative effectiveness of the various retardants wes not apparent.

According to the works of Esteve and Laible (10), the brominated tri-allyl phosphate was the outstanding lame-retardant in the group of compounds investigated. There was no evidence obtained substantiating this conclusion in the data obtained from the combustion experiments. 
oxidation of the char obtained from the pyrolyeis of cellulose treated with catalytio amounts of retardants exhibited a marked increase in the production of carbon monoxide when compared with the char from the untreated sample (Table 3). A comparison of these data and the results of the afterglow tests (10) on fabric treated with similar add-ons showed no correlation. The treated fabric exhibited considerable afterglow, comparable to an untreated sample.

similar reaults were obtained from samples treated with 10 to 20 per cent add-on (Table 4). There was no correlation with similarly treated fabrics which exhibited varylng degrees of afterglow.

The char-rolatiles ratio was no indication of effectiveness because of the added weight of the decomposition products of the retardant.

The results obtalned from these experiments provide evidence supporting the theory that flame-resistant cellulose, when compared with untreated cellulose, produces less flammable tars and an increased amount of carbon monoxide. There was no significant differentiation possible as to relative effectiveness of the various compounds investigated. This lack of correlation suggests that these methods of evaluating the relative effectiveness of other fire-retardants are not conclusive.

It is suggested that studies be made as to the types of compounds exhibiting fire-retardancy. A theory that 
should be expanded requires compounds that are capable of hydrogen bonding. If these compounds were absorbed by the cellulose fiber there is the possibility that they might combine with the hydroxyl groups and direct the degradation of cellulose toward larger, less volatile fragments, e.1., the phosphoric acid released from the organo-phosphorous compounds:

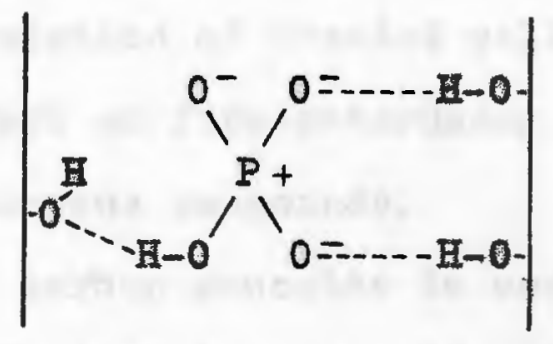

Hydrogen Bonding Between Phosphate and Cellulose Molecules 


\section{SUMMARY}

1. The charred residue and flammable tars produced from the combustion and pyrolysis of cellulose treated w1th various organo-phosphorous compounds were investigated.

2. The treated cellulose produced an increase in the amount of char and a lesser amount of flammable tars when compared with an untreated sample.

3. There was no correlation between the products of the thermal degradation of treated cellulose and the relative effect on fire-retarancy of the added organo-phosphorous compounds.

4. The ratio of carbon monoxide to carbon dioxide produced in the oxidation of the charred residue from the pyrolysis of treated cellulose was determined.

5. The treated cellulose produced an increase in the carbon monoxide-carbon dioxide ratio when compared with an untreated sample.

6. There was no correlation between the carbon monoxidecarbon dioxide ratio and afterglow of the treated samples.

7. There we.s no compound in the group of retardants investigated that was outstanding in directing the decomposition of celluloge toward the production of less flammable tars and a greater ratio of carbon monoxide to carbon dioxide.

8. When the retardants investigated were applied in catalytic amounts there was little effect observed on 
the fire-retardancy of cellulose.

9. These methods, flammable tar formation and carbon monoxide-carbon dioxide ratio, for evaluating the relative effectiveness of fire-retardant for cellulose are not conclusive.

10. It is recommended that further studies be completed on the type of compounds imparting fire-retardant properties when applied to cellulose in oraer to develop a more general theory. 


\section{APPENDIXES}

Thb-a 2y. 
Table 1a. Experimental Data Summarized in Table 1.

Compound

\begin{tabular}{|c|c|c|c|c|c|}
\hline \multicolumn{2}{|c|}{ Add-on, } & \multicolumn{2}{|c|}{$\begin{array}{c}\text { Char, } \\
\%\end{array}$} & \multicolumn{2}{|c|}{ Tar, } \\
\hline I. & 2 & 10 & 2 & 1. & 2. \\
\hline & & * & * & 43.54 & 43.18 \\
\hline 1.25 & 1.24 & 3.87 & 3.29 & 18.39 & 18.99 \\
\hline 1.11 & 1.12 & & 1.89 & 25.39 & 24.69 \\
\hline 1.02 & 1.01 & 4 & 1.34 & 23.83 & 24.83 \\
\hline 1.35 & 1.36 & 1.51 & 1.83 & 83 & 20.63 \\
\hline 0.89 & 0.83 & 1.91 & 1.79 & 24.44 & 24.80 \\
\hline
\end{tabular}

Table 2a. Experimental Data Summarized in Table 2.

Compound

Blank

Modified Triallyl

Phosphate

Brominated Triallyl

Phosphite

Brom. Modified

Triallyl Phosphate

Brom. b18-Allyl, n-Butyl Phosphate Brominated Aniline Triallyl Phosphite
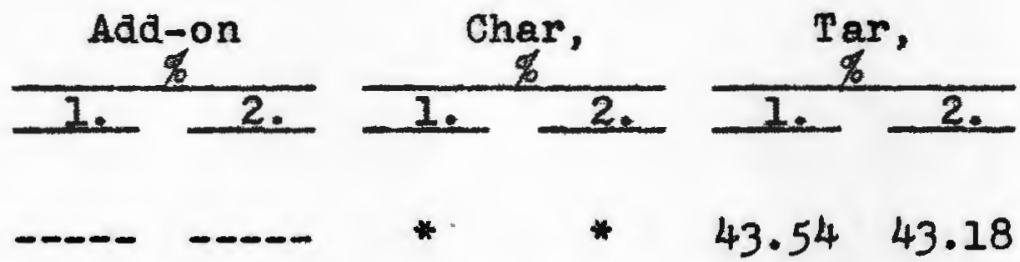

$43.54 \quad 43.18$

23.6523 .73

$15.74 \quad 16.12$

$19.84 \quad 19.18$

$\begin{array}{llllll}15.65 & 16.19 & 11.10 & 11.94 & 18.82 & 18.00\end{array}$

$\begin{array}{llllll}13.87 & 14.19 & 9.46 & 9.64 & 16.23 & 16.09\end{array}$

$\begin{array}{llllll}21.02 & 20.06 & 12.20 & 11.62 & 15.91 & 16.73\end{array}$

$\begin{array}{llllll}17.01 & 16.35 & 15.95 & 15.13 & 16.91 & 17.77\end{array}$

(*) Impossible to recover char. 
Table 3a.

Retardant Used in the Gas Analyses

compound

Catalytic

Amounto. \%

$10-20 \%$

Tـ

Amountag

Add-on

Modified Triallyl

Phosphate

Brominated Priallyl

Phosphite

Brom. Modified Triallyl

Phosphate

Brom. b1s-Allyl, n-Butyl,

Phosphate

Brominated Aniline

Triallyl Phosphtte

1.081

13.53

$1.723 \quad 18.68$

$0.929 \quad 13.09$

$1.317 \quad 17.08$

$1.421 \quad 11.29$ 


\section{ACKNOWLEDGEMENTS}

The author wiahes to express his sincere appreciation to Dr. W. George Parks who made this investigation possible; to Dr. H. C. Harrison for his helpful suggestions in the gas analyses; and to Dr. R. M. Estere and Mr. R. C. Laible for their information and contribution of the flameretardants. Grateful acknowledgenents are extended to the other members of the chemistry department for their cooperation and suggestions. 


\section{BIBLIOGRAPHY}

1. Church, James M., Little, Robert W., Coppick, Syaney. 1950. Evaluation of Flame Resistant Fabrics. Ind. Eng. Chem., 42: 418-419.

2.

1950. Thermal Behavior of Fabrics at Flaming Temperatures. Ind. Eng. Chem., 42: 415.

3. Church, James M. 1945. The Flameproofing of Army Clothing, N.R.C. Proj. QMC. No. 27, National Research Counc1l Laboratories, Columbia Unit., New York. (a) p.12-13; (b) p.14; (c) p.16,17.

4. Little, Robert W. 1947. Flameprooling Textile Fabrics. Reinhola Publishing Co., New York. (a) p.61; (b) p.85; (c) p.88; (d) p.89; (e) p.46; (f) p.41.

5. - 1945. Investigation of the Tarry Products Resulting from the Thermal Decomposition of Cellulosic Materials, N.R.C. Proj. Q.M.C. No. 27, Final Report, Subproj. 27-R6. N.R.C. Lab., Columbia Univ., New York. (abstract).

6. Hurd, Charles, D. 1929. The Pyrolysis of Carbon Compounds. The Chemical Catalog Co., Inc., New York. p.283. 
7. Heuser, Emil. 1944. The Chemistry of Cellulose. John Wiley and Sons. New York. p.545.

8. Copplck, Sydney. 1944. The Thermal Decomposition of Cellulose and Fire-Retardant Combinations. N.R.C. Proj. Q.M.C. No. 27, Final Report, Subproj. 27-R2. N.R.C. Lab., Columbia Univ., New York. p.2-3.

9. Little, Robert W., Church, James M., Copplck, Sidney. 1950. Commercial Application of Flame-Resistant Finishes. Ind. Eng. Chem., 42: p.432-433.

10. Esteve, R.M. and Laible, R.C. Private Communication, February 13, 1952. 